\title{
Centrally acting cholecystokinin induces depressor circulatory effects in haemorrhage-shocked rats
}

\author{
Ośrodkowo działająca cholecystokinina wywołuje działanie depresyjne \\ na układ krążenia u szczurów we wstrząsie krwotocznym \\ Karolina Jasikowska1 ${ }^{\text {ID }}$, Magdalena A. Zając ${ }^{2}$ (D) , Jerzy Jochem ${ }^{1}$ \\ ${ }^{1}$ Katedra i Zakład Fizjologii, Wydział Nauk Medycznych w Zabrzu, Śląski Uniwersytet Medyczny w Katowicach \\ ${ }^{2}$ Wydział Lekarski, Uniwersytet Medyczny im. Piastów Śląskich we Wrocławiu
}

\begin{abstract}
INTRODUCTION: Cholecystokinin (CCK) is a peptide gastrointestinal hormone involved in the stimulation of lipid and protein digestion as well as a neurotransmitter/neuromodulator in the central nervous system. After intravenous administration, it induces a resuscitating effect in rats subjected to haemorrhagic shock. Since CCK is able to directly and indirectly affect the cardiovascular centre function, the aim of the study was to examine the action of the sulphated octapeptide form of CCK (CCK-8) given intracerebroventricularly (icv) in the sympathoinhibitory phase of haemorrhagic shock.

MATERIAL AND METHODS: Studies were carried out in male Wistar rats anaesthetized with ketamine/xylazine $(100 \mathrm{mg} / \mathrm{kg}+10 \mathrm{mg} / \mathrm{kg}$, intramuscularly) and subjected to irreversible haemorrhagic shock ( $0 \%$ survival at $2 \mathrm{~h})$ with a mean arterial pressure (MAP) of 20-25 mmHg. At 5th min of critical hypotension, the rats were injected icv with CCK-8 $(5,15 \mathrm{nmol})$ or saline $(5 \mu \mathrm{l})$.

RESULTS: Haemorrhage led to a decrease in pulse pressure (PP), heart rate (HR) as well as increases in renal (RVR) and mesenteric vascular resistance (MVR). In the control group injected with saline, there were no significant increases in the measured cardiovascular parameters, and the survival time was $32.5 \pm 5.1 \mathrm{~min}$. CCK-8 induced dose-dependent decreases in MAP, PP and HR accompanied by increases in RVR and MVR, and also shortened the survival time in comparison to the control animals.
\end{abstract}

CONCLUSIONS: Centrally acting CCK-8 induces depressive circulatory effects in haemorrhage-shocked rats.

KEY WORDS

cholecystokinin, rats, haemorrhagic shock

\section{STRESZCZENIE}

WSTĘP: Cholecystokinina (CCK) należy do hormonów peptydowych układu pokarmowego regulujących trawienie lipidów i białek, a ponadto jest ośrodkowym neurotransmiterem/neuromodulatorem. Po podaniu dożylnym wywołuje efekt resuscytacyjny u szczurów we wstrząsie krwotocznym. Ze względu na fakt, iż CCK może wpływać bezpośrednio i pośrednio na czynność ośrodka sercowo-naczyniowego, celem pracy było zbadanie działania pochodnej siarczanowej oktapeptydu CCK (CCK-8) podawanej do komory bocznej mózgu (intracerebroventricularly - icv) w fazie hamowania czynności układu współczulnego we wstrząsie krwotocznym.

Received: 03.09.2020 Revised: 10.10.2020 Accepted: 10.10.2020 Published online: 19.03 .2021

Address for correspondence: prof. dr hab. n. med. Jerzy Jochem, Katedra i Zakład Fizjologii, Wydział Nauk Medycznych w Zabrzu, Śląski Uniwersytet Medyczny w Katowicach, ul. Jordana 19, 41-808 Zabrze, Polska, tel. +48 32272 23 62, e-mail: jjochem@sum.edu.pl

Copyright @ Śląski Uniwersytet Medyczny w Katowicach www.annales.sum.edu.pl 
MATERIA I METODY: Badania przeprowadzono u samców szczurów szczepu Wistar w znieczuleniu ogólnym (ketamina $[100 \mathrm{mg} / \mathrm{kg}] / \mathrm{ksylazyna}[10 \mathrm{mg} / \mathrm{kg}])$, u których wywołano nieodwracalny wstrząs krwotoczny $(0 \%$ przeżycia $2 \mathrm{~h})$ ze średnim ciśnieniem tętniczym (mean arterial pressure - MAP) 20-25 mmHg. W 5 min krytycznej hipotensji szczurom podawano icv CCK-8 $(5,15 \mathrm{nmol})$ lub $0,9 \%$ roztwór $\mathrm{NaCl}(5 \mu \mathrm{l})$.

WYNIKI: Krwotok prowadził do obniżenia ciśnienia tętna (pulse pressure - PP), częstości rytmu serca (heart rate - HR) oraz wzrostu nerkowego (renal vascular resistance - RVR) i krezkowego oporu naczyniowego (mesenteric vascular resistance - MVR). W grupie kontrolnej nie stwierdzono wzrostu badanych parametrów układu krążenia, a średni czas przeżycia wynosił 32,5 $\pm 5,1$ min. CCK-8 wywoływała zależne od dawki spadki MAP, PP i HR ze wzrostem RVR i MVR, a także skracała czas przeżycia w porównaniu ze zwierzętami kontrolnymi.

WNIOSKI: Ośrodkowo działająca CCK-8 wywołuje działanie depresyjne na układ krążenia u szczurów we wstrząsie krwotocznym.

\author{
SŁOWA KLUCZOWE \\ cholecystokinina, szczury, wstrząs krwotoczny
}

\section{INTRODUCTION}

Cardiovascular responses to a progressive blood loss in mammals include three consecutive phases: (1) the sympathoexcitatory phase, (2) sympathoinhibitory phase and (3) not always present, a terminal transient increase in sympathetic activity [1]. The presympathetic neurones located in the rostral ventrolateral medulla (RVLM) play a pivotal role in maintaining the sympathetic tone and, thus, directly determine the response of cardiovascular compensatory mechanisms to haemorrhage. RVLM, together with the nucleus of the solitary tract (NTS) and the caudal ventrolateral medulla are structures involved in triggering the baroreceptor and Bezold-Jarisch reflexes, which characterize the first and second phase of cardiovascular response to hypovolaemia, respectively [2].

Central neurotransmitters and neuromodulators responsible for the regulation of presympathetic neurone activity in critical hypovolaemia, according to an original hypothesis by Bertolini [3], can be classified into analgesic (opioid) and anti-analgesic (non-opioid) agents. Generally, opioid peptides are able to decrease the activity of the RVLM neurones, whereas non-opioid transmitters prolong an initial, sympathoexcitatory phase.

Non-opioid neurotransmitters/neuromodulators such as proopiomelanocortin (POMC) peptides (adrenocorticotropin $[\mathrm{ACTH}]$ and ACTH fragments, melanocyte-stimulating hormone $\alpha$ ) and thyrotropin-releasing hormone are able to induce a resuscitating effect after central or peripheral administration $[3,4]$. Our previous studies clearly demonstrate the anti-shock effects of centrally acting histamine, which can also be classified as a non-opioid (anti-analgesic) neurotransmitter [5]. As we showed, both exogenous histamine administered intracerebroventricularly (icv) as well as endogenous histamine released from histaminergic neurones are able to evoke a resuscitating effect in an irreversible model of haemorrhagic shock in rats, with involvement of the sympathetic and the renin-angiotensin systems as well as arginine vasopressin and POMC-derived peptides [6].

Cholecystokinin (CCK) is a peptide gastrointestinal hormone secreted mainly from enteroendocrine I-cells, involved in the stimulation of lipid and protein digestion. Except for the gastrointestinal system, CCK is produced by neurones in the central and peripheral nervous systems, where it acts as a neurotransmitter/ neuromodulator [7]. CCK evokes biological effects via two types of receptors: CCK-1 (CCK-A) receptors are present mainly in peripheral tissues and in discrete brain regions, while CCK-2 (CCK-B) receptors predominate in the central nervous system [8]. The sulphated octapeptide form of CCK (CCK-8) is an agonist of both types of receptors [8]. Acting centrally, CCK mediates satiety [9], induces anxiety [10] and depression [11] and influences memory processes [12].

CCK is also able to affect the function of presympathetic RVLM neurones acting directly and indirectly. CCK receptors are expressed at the neurones of the NTS and RVLM and influence their activity $[13,14]$. Although CCK as a peptide does not cross the blood-brain barrier, it may act on neurones located at the area postrema, which belongs to circumventricular organs, from where information is sent by axons to many brain regions [15]. In addition, CCK receptors are present on vagal afferents that can transfer information to the NTS [16]. CCK-8 given intravenously (iv) induces decreases in MAP, HR, splanchnic sympathetic nerve discharge in addtition to a transient increase in lumbar sympathetic nerve discharge in halothane anaesthetized Sprague-Dawley rats [14]. CCK-8 acting via CCK-1 receptors on vagal afferents inhibits approximately $49 \%$ and stimulates approximately $28 \%$ of RVLM presympathetic neurones [14]. In contrast, in urethane anaesthetized Wistar rats, there is a biphasic response to CCK- 8 - an initial decrease in arterial pressure mediated by CCK-1 receptors on vagal afferents followed by a pressor response mediated by activation of CCK-1 receptors in the central nervous system [17].

Interestingly, CCK-8 administered iv to rats subjected to endotoxic shock evokes an increase in blood pressure, reduction in the lesion in the main organs and a rise in the survival rate [18]. Similarly, Guarini et al. [19] showed the prompt increase in arterial pressure with animprovement in tissue oxygenation and an increase in circulating blood volume resulting from iv administered CCK-8. Since peripherally administered CCK-8 in shock is able to affect RVLM neurone acti- 
vity directly and indirectly - acting via vagal terminals and neurones located at NTS and circumventricular organs, the aim of the present study was to clarify the direct effects of centrally acting CCK-8 on cardiovascular centre neurones in the sympathoinhibitory phase of haemorrhagic shock in rats.

\section{MATERIAL AND METHODS}

\section{Animals}

All the procedures were performed according to EU directives and approved by the Local Ethics Committee, Katowice, Poland (Notifications Nos. 99/2015 and $38 / 2012$ ). The studies were performed on male Wistar rats weighing 235-270 g (4-6 months old), housed in individual cages in the animal colony, under controlled conditions (temperature $20-22^{\circ} \mathrm{C}$, humidity $60-70 \%$, $12 \mathrm{~h} \mathrm{light/dark} \mathrm{cycle)} \mathrm{and} \mathrm{provided} \mathrm{with} \mathrm{food} \mathrm{and} \mathrm{water}$ ad libitum.

\section{Surgical preparation}

After inducing general anaesthesia with ketamine/xylazine $(100 \mathrm{mg} / \mathrm{kg}+10 \mathrm{mg} / \mathrm{kg}$ intramuscularly, supplemented if required), the rats were implanted with catheters filled with heparinised saline $(100 \mathrm{IU} / \mathrm{ml})$ in the right femoral artery and vein. The mean arterial pressure (MAP) and heart rate (HR) were measured using a TAM-A transducer amplifier module and an ECGA amplifier (Hugo Sachs Elektronik, Germany), respectively.

Electromagnetic perivascular probes (type $1 \mathrm{RB}$ and 2.5SB, Hugo Sachs Elektronik, Germany) were implanted around the right renal and superior mesenteric arteries to monitor renal (RBF) and mesenteric blood flow (MBF) using a transit time flowmeter module (TTFM; Transonic Systems Inc., USA). All the measurements of blood flow were started after a 30-min adaptation period to avoid the influences of probe implantation.

Renal (RVR) and mesenteric vascular resistance (MVR) were calculated by dividing the MAP (in $\mathrm{mmHg}$ ) by $\mathrm{RBF}$ or MBF (in $\mathrm{ml} / \mathrm{min}$ ), respectively.

\section{Experimental protocol}

For the icv treatment, the rats were prepared 3-5 days before the experiment by implantation of polyethylene cannulae, under ketamine/xylazine anaesthesia, into the right brain lateral ventricle as previously described [5]. All icv injections were made in the volume of $5.0 \mu \mathrm{l}$; correctness of the injections was verified [5].

Irreversible haemorrhagic shock, according to the method by Guarini et al. [19], was produced by intermittent blood withdrawal from the catheter inserted into the right femoral vein over a period of 15-25 min, until
MAP decreased to and stabilised at 20-25 mmHg (maximal blood outflow rate $1 \mathrm{ml} / \mathrm{min}$ ). Five minutes after the termination of bleeding, the animals were injected icv with $5 \mu \mathrm{l}$ of a $0.9 \%$ saline solution (control group) or $\operatorname{CCK}(5,15 \mathrm{nmol})$. The doses of CCK were taken from literature [20].

The animals were continuously monitored until death. Body temperature was monitored by a rectal thermometer and maintained at $37 \pm 0.5^{\circ} \mathrm{C}$ using heating lamps. All the experiments were performed between 8.00 am and $2.00 \mathrm{pm}$.

\section{Drugs}

The following drugs were used: heparin (Polfa, Poland), CCK-8 (Tocris Bioscience, UK), ketamine hydrochloride, xylazine (Biowet Sp. z o. o., Poland). All the drug solutions were prepared freshly on the day of the experiment.

\section{Statistics}

All the values are given as means $\pm \mathrm{SD}$, with $\mathrm{p}<0.05$ considered as the level of significance. Statistical evaluation of the other results was performed using analysis of variance (ANOVA) and the Student-Newman-Keuls post-ANOVA test.

\section{RESULTS}

The initial pre-bleeding values of MAP, pulse pressure (PP), HR, RVR and MVR did not reveal significant differences between the groups, the values being in the control saline-treated group: $97.6 \pm 5.4 \mathrm{mmHg}, 36.1 \pm$ $5.6 \mathrm{mmHg}, 287 \pm 17$ beats $/ \mathrm{min}, 18.7 \pm 4.3 \mathrm{mmHg} / \mathrm{ml} /$ min and $13.7 \pm 3.5 \mathrm{mmHg} / \mathrm{ml} / \mathrm{min}$, respectively.

The total bleeding volume necessary to induce critical hypotension in all the animals was $2.43 \pm 0.31 \mathrm{ml} / 100 \mathrm{~g}$ body weight.

In the control group, a decrease in MAP to $20-25 \mathrm{mmHg}$ was accompanied by a reflex-induced decrease in HR to $168 \pm 21$ beats/min, as well as increases in RVR and MVR to $26.1 \pm 4.1 \mathrm{mmHg} / \mathrm{ml} / \mathrm{min}$ and $24.2 \pm$ $3.8 \mathrm{mmHg} / \mathrm{ml} / \mathrm{min}$, respectively. There were no differences between the groups regarding post-bleeding cardiovascular parameters (Table I).

In the control group, there were no significant increases in the measured cardiovascular parameters after saline treatment, and the survival time was $32.5 \pm 5.1 \mathrm{~min}$.

CCK-8 given icv at 5 min of critical hypotension induced dose-dependent decreases in MAP, PP and HR accompanied by increases in RVR and MVR (Table I). CCK-8 given in doses of 5 and $15 \mathrm{nmol}$ icv significantly shortened the survival times to $16.6 \pm 5.1$ and $23.6 \pm 6.4 \mathrm{~min}$, respectively. 
Table I. Influence of CCK-8 and saline on measured cardiovascular parameters in haemorrhagic shock in rats Tabela I. Wpływ CCK-8 i 0,9\% roztworu $\mathrm{NaCl}$ na badane parametry układu krążenia we wstrząsie krwotocznym u szczurów

\begin{tabular}{|c|c|c|c|c|}
\hline \multirow{2}{*}{ Parameter/Treatment } & \multirow{2}{*}{ Before bleeding } & \multirow{2}{*}{ After bleeding } & $5 \mathrm{~min}$ & $10 \mathrm{~min}$ \\
\hline & & & \multicolumn{2}{|c|}{ after treatment } \\
\hline \multicolumn{5}{|l|}{ MAP (mmHg) } \\
\hline Saline & $97.6 \pm 5.4$ & $23.4 \pm 1.7$ & $23.1 \pm 1.6$ & $22.5 \pm 2.4$ \\
\hline CCK-8 (5 nmol) & $95.4 \pm 7.6$ & $23.1 \pm 1.6$ & $22.1 \pm 1.7$ & $16.8 \pm 2.2^{*}$ \\
\hline CCK-8 (15 nmol) & $93.6 \pm 7.8$ & $22.1 \pm 2.3$ & $18.4 \pm 1.9^{*}$ & $15.2 \pm 2.6^{*}$ \\
\hline \multicolumn{5}{|l|}{$\mathrm{PP}(\mathrm{mmHg})$} \\
\hline Saline & $36.1 \pm 5.6$ & $7.3 \pm 2.6^{\#}$ & $9.8 \pm 2.5^{\#}$ & $10.2 \pm 2.4^{\#}$ \\
\hline CCK-8 (5 nmol) & $39.5 \pm 8.5$ & $6.6 \pm 1.9^{\#}$ & $5.6 \pm 1.7^{\# \star}$ & $4.6 \pm 1.8^{\# *}$ \\
\hline CCK-8 (15 nmol) & $33.9 \pm 6.5$ & $7.9 \pm 2.1^{\#}$ & $5.1 \pm 1.8^{\# *}$ & $3.7 \pm 1.9^{\# *}$ \\
\hline \multicolumn{5}{|l|}{ HR (beats/min) } \\
\hline Saline & $287 \pm 17$ & $168 \pm 21^{\#}$ & $155 \pm 22^{\#}$ & $147 \pm 17^{\#}$ \\
\hline CCK-8 (5 nmol) & $305 \pm 23$ & $172 \pm 18^{\#}$ & $142 \pm 18^{\#}$ & $88 \pm 20^{\# *}$ \\
\hline CCK-8 (15 nmol) & $279 \pm 24$ & $155 \pm 24^{\#}$ & $114 \pm 15^{\# \star}$ & $95 \pm 16^{\# *}$ \\
\hline \multicolumn{5}{|l|}{$\mathrm{RVR}(\mathrm{mmHg} / \mathrm{m} / \mathrm{min})$} \\
\hline Saline & $18.7 \pm 4.3$ & $26.1 \pm 4.1^{\#}$ & $23.8 \pm 3.5^{\#}$ & $27.9 \pm 4.1^{\#}$ \\
\hline CCK-8 (5 nmol) & $16.1 \pm 3.7$ & $24.6 \pm 3.8^{\#}$ & $25.8 \pm 3.2^{\#}$ & $34.4 \pm 4.8^{\# *}$ \\
\hline CCK-8 (15 nmol) & $18.2 \pm 4.7$ & $25.5 \pm 4.2^{\#}$ & $28.6 \pm 4.2^{\# \star}$ & $36.3 \pm 5.1^{\# \star}$ \\
\hline \multicolumn{5}{|l|}{$\operatorname{MVR}(\mathrm{mmHg} / \mathrm{m} / / \mathrm{min})$} \\
\hline Saline & $13.7 \pm 3.5$ & $24.2 \pm 3.8^{\#}$ & $20.4 \pm 4.2^{\#}$ & $21.8 \pm 3.7^{\#}$ \\
\hline CCK-8 (5 nmol) & $14.7 \pm 4.1$ & $25.1 \pm 3.5^{\#}$ & $28.5 \pm 4.8^{\# \star}$ & $32.5 \pm 4.2^{\# \star}$ \\
\hline CCK-8 (15 nmol) & $13.2 \pm 4.4$ & $25.7 \pm 4.2^{\#}$ & $30.4 \pm 4.9^{\# *}$ & $36.3 \pm 4.7^{\# *}$ \\
\hline
\end{tabular}

$\# p<0.05$ in comparison to pre-bleeding value

$* p<0.05$ in comparison to control group

\section{DISCUSSION}

Haemorrhagic shock is a life-threatening condition, and therefore, studies on the mechanisms involved in cardiovascular control, especially responsible for the regulation of RVLM neurone activity in shock, are of essential importance. The present study demonstrates for the first time that centrally administered CCK-8 induces depressor circulatory effects in haemorrhagic shock in rats.

The study is a continuation of our research concerning the role of centrally acting neurotransmitters/neuromodulators in cardiovascular regulation in haemorrhagic shock $[5,6,21,22]$. We used here a model of irreversible pressure-controlled haemorrhagic shock introduced by Guarini et al. [19]. We confirmed that bleeding to $20-25 \mathrm{mmHg}$ with the loss of approximately $40 \%$ of the total blood volume (2.0-2.5 ml/100 g body weight) leads to early initiation of the sympathoinhibitory phase of regulation, which is typical for a reaction to increasing hypovolaemia in anaesthetised rodents [2] and the death of all the animals in the control group within $40 \mathrm{~min}$. As we previously demonstrated, that model is characterised by a critical reduction to $15-25 \%$ of cardiac output, peripheral blood flows [23] as well as the development of metabolic acidosis [24]. In this model of shock, not only the role of endogenous neurotransmitters/neuromodulators can be assessed but also the effectiveness of different therapeutic methods of resuscitation can be compared. However, according to our experience, it is useful to rather demonstrate the action of strong anti-shock agents/mechanisms, such as centrally acting POMC-derived peptides $[3,4]$ or histamine $[5,6]$. In the case of slow-acting agents/treatments, models of reversible haemorrhagic shock should be applied.

CCK-8 can affect central cardiovascular regulation acting directly in the central nervous system and indirectly - via vagal afferents. Therefore, to avoid the possible peripheral mechanisms of CCK-8 action, to study the influence on the brain level, we decided to administer the peptide directly into the brain ventricle (icv). We demonstrated a decrease in MAP, PP and $\mathrm{HR}$, accompanied by high regional vascular resistance. We hypothesize that the depressor effect resulting in lowered MAP, PP and HR is caused by withdrawal of the sympathetic tone as a result of direct or indirect action on presympathetic neurones. On the other hand, as we demonstrated previously, the high values of peripheral vascular resistance, calculated from MAP and 
peripheral blood flows, are typical for the pre-terminal period of irreversible haemorrhagic shock [6]. As hypothesized, they result from the activation of humoral compensatory mechanisms in shock [2]. We showed that after the activation of neural compensatory mechanisms by centrally acting histamine, there is a mobilisation of blood from venous reservoirs with a subsequent increase in the volume of circulating blood and decreases in peripheral vascular resistance [6]. In addition, CCK-8 led to a significant decrease in the survival time. These effects are completely different from those observed by Guarini et al. [19] after the peripheral (iv) administration of CCK-8. The difference can be explained by the different site of CCK- 8 action and types of activated compensatory mechanisms. The mechanisms of action of CCK-8 administered iv can be associated with CCK-8-mediated activation of the vagal anti-inflammatory pathway [25]. It is postulated that CCK- 8 may activate afferent signals through ascending vagal fibres that act as the sensory arm of an "inflammatory reflex" [26]. The subsequent activation of vagal parasympathetic fibres (the descending arm of the "inflammatory reflex") leads to the release of acetylcholine in the organs of the reticuloendothelial system. Acetylcholine can interact with $\alpha 7$ subunit-containing nicotinic receptors on macrophages and other immune cells as well as inhibit the synthesis and release of pro-inflammatory cytokines. This cholinergic anti-inflammatory pathway is integrated at the brain level [25].

Our present data support the thesis of Guarini et al. [26] that cholinergic mechanisms are involved in the anti-shock effect of both melanocortin peptides and CCK-8; however, the sites of the action appear to be in the brain in the case of melanocortins, and outside the central nervous system in that of CCK-8. In addition, studies in pithed vagotomized rats demonstrate that CCK-8 acting via CCK-1 receptors induces a dose-dependent increase in MAP with bradycardia [27]. The pressor effect is probably indirect, at least in part mediated via $\alpha$-adrenoceptors, whereas bradycardia is evoked by the direct action of CCK in the heart [27].

Although our results clearly show the depressive circulatory effects of centrally acting CCK-8 in rats subjected to haemorrhagic shock, there are some limitations of our study. Firstly, CCK-8 was injected icv which is an accepted route of administering poorly-transferring agents via the blood-brain barrier; nonetheless, this method is not possible to use in clinical conditions and is reserved for experimental animal studies. Secondly, we did not show precisely the target neurones responsible for the depressor effect; we can only suggest direct or indirect action on RVLM neurones. Finally, we cannot exclude possible interactions between CCK-8 and other neuronal systems, which can secondarily inhibit RVLM neurone activity; the identification of these systems will be the purpose of our further studies.

In conclusion, our study demonstrates for the first time centrally acting CCK-8-mediated depressive circulatory effects in haemorrhage-shocked rats. We suggest that the peripheral (iv) administration of CCK receptor antagonists, which can easily pass the blood-brain barrier, could be a method of activating presympathetic neurones in the second phase of cardiovascular regulation in haemorrhagic shock and that hypothesis requires further studies.

This research was supported by the Medical University of Silesia, Katowice grant (KNW-1-035/N/7/O).

\section{Author's contribution}

Study design - K. Jasikowska, J. Jochem

Data collection - K. Jasikowska

Data interpretation - K. Jasikowska, J. Jochem, M.A. Zając

Statistical analysis - M.A. Zajac, J. Jochem

Manuscript preparation - J. Jochem, K. Jasikowska, M.A. Zając

Literature research - M.A. Zając, J. Jochem

\section{REFERENCES}

1. Jacobsen J., Secher N.H. Heart rate during haemorrhagic shock. Clin Physiol. 1992; 12(6): 659-666, doi: 10.1111/j.1475-097x.1992.tb00369.x.

2. Schadt J.C., Ludbrook J. Hemodynamic and neurohumoral responses to acute hypovolemia in conscious mammals. Am. J. Physiol. 1991; 260(2 Pt 2): H305-H318, doi: 10.1152/ajpheart.1991.260.2.H305.

3. Bertolini A. The opioid/anti-opioid balance in shock: a new target for therapy in resuscitation. Resuscitation 1995; 30(1): 29-42, doi: 10.1016/03009572(94)00863-b.

4. Bertolini A., Ferrari W., Guarini S. The adrenocorticotropic hormone (ACTH)-induced reversal of hemorrhagic shock. Resuscitation 1989; 18(2-3): 253-267, doi: 10.1016/0300-9572(89)90027-0.

5. Jochem J. Cardiovascular effects of histamine administered intracerebroventricularly in critical haemorrhagic hypotension in rats. J. Physiol. Pharmacol 2000; 51(2): 229-239.
6. Jochem J., Kasperska-Zajac A. The role of the histaminergic system in the central cardiovascular regulation in haemorrhagic hypotension. Folia Med. Cracov. 2012; 52(3-4): 31-41.

7. Hökfelt T., Cortés R., Schalling M., Ceccatelli S., Pelto-Huikko M., Persson H., Villar M.J. Distribution patterns of CCK and CCK mRNA in some neuronal and non-neuronal tissues. Neuropeptides 1991; 19 Suppl: 31-43, doi: 10.1016/0143-4179(91)90081-s.

8. Fink H., Rex A., Voits M., Voigt J.P. Major biological actions of CCK a critical evaluation of research findings. Exp. Brain Res. 1998; 123(1-2): 77-83, doi: $10.1007 / \mathrm{s} 002210050546$

9. Zanchi D., Depoorter A., Egloff L., Haller S., Mählmann L., Lang U.E. et al. The impact of gut hormones on the neural circuit of appetite and satiety: A systematic review. Neurosci. Biobehav. Rev. 2017; 80: 457-475, doi: 10.1016/j.neubiorev.2017.06.013. 
10. Harro J. CCK and NPY as anti-anxiety treatment targets: promises, pitfalls, and strategies. Amino Acids 2006; 31(3): 215-230, doi: 10.1007/s00726-0060334-x

11. Shen C.J., Zheng D., Li K.X., Yang J.M., Pan H.Q., Yu X.D. et al. Cannabinoid $\mathrm{CB}_{1}$ receptors in the amygdalar cholecystokinin glutamatergic afferents to nucleus accumbens modulate depressive-like behavior. Nat. Med. 2019; 25(2): 337-349, doi: 10.1038/s41591-018-0299-9.

12. Whissell P.D., Bang J.Y., Khan I., Xie Y.F., Parfitt G.M., Grenon M. Selec tive activation of cholecystokinin-expressing GABA (CCK-GABA) neurons enhances memory and cognition. eNeuro 2019; 6(1): ENEURO0360-18.2019, doi: 10.1523/ENEURO.0360-18.2019.

13. Roman C.W., Derkach V.A., Palmiter R.D. Genetically and functionally defined NTS to PBN brain circuits mediating anorexia. Nat. Commun. 2016; 7 : 11905, doi: 10.1038/ncomms11905.

14. Sartor D.M., Verberne A.J. Cholecystokinin selectively affects presympathetic vasomotor neurons and sympathetic vasomotor outflow. Am. J. Physiol. Regul. Integr. Comp. Physiol. 2002; 282(4): R1174-1184, doi: 10.1152/ajpregu.00500.2001

15. Sugeta S., Hirai Y., Maezawa H., Inoue N., Yamazaki Y., Funahashi M. Presynaptically mediated effects of cholecystokinin- 8 on the excitability of area postrema neurons in rat brain slices. Brain Res. 2015; 1618: 83-90, doi: 10.1016/j.brainres.2015.05.018

16. Verberne A.J., Sartor D.M. CCK-induced inhibition of presympathetic vasomotor neurons: dependence on subdiaphragmatic vagal afferents and central NMDA receptors in the rat. Am. J. Physiol. Regul. Integr. Comp. Physiol. 2004; 287(4): R809-816, doi: 10.1152/ajpregu.00258.2004.

17. Kaczyńska K., Szereda-Przestaszewska M. Contribution of CCK1 receptors to cardiovascular and respiratory effects of cholecystokinin in anesthetized rats. Neuropeptides 2015; 54: 29-34, doi: 10.1016/j.npep.2015.08.006.

18. Ling Y.L., Huang S.S., Wang L.F., Zhang J.L., Wan M., Hao R.L. Cholecystokinin-octapeptide (CCK-8) reverses experimental endotoxin shock. Shen Li Xue Bao 1996; 48(4): 390-394.
19. Guarini S., Bazzani C., Leo L., Bertolini A. Haematological changes induced by the intravenous injection of CCK-8 in rats subjected to haemorrhagic shock. Neuropeptides 1988; 11(2): 69-72, doi: 10.1016/0143-4179(88)90012-1.

20. Felicio L.F., Mann P.E., Bridges R.S. Intracerebroventricular cholecystokinin infusions block beta-endorphin-induced disruption of maternal behavior. Pharmacol. Biochem. Behav. 1991; 39(1): 201-204, doi: 10.1016/00913057(91)90422-x.

21. Krawiec A., Jasikowska K., Chojnacka K., Mitera A., Jochem J. Involvement of central histaminergic system in cardiovascular effects of Y1 receptor antagonist BIBP 3226 in haemorrhagic shock in rats. Ann. Acad. Med. Siles. 2017; $71: 357-362$, doi: $10.18794 /$ aams/67571.

22. Jochem J., Żak A., Rybczyk R., Irman-Florjanc T. Interactions between the serotonergic and histaminergic systems in the central cardiovascular regulation in haemorrhage-shocked rats: involvement of 5-HT(1A) receptors. Inflamm. Res. 2009; 58(Suppl 1): S38-S40, doi: 10.1007/s00011-009-0658-6.

23. Jochem J. Central histamine-induced reversal of critical haemorrhagic hypotension in rats - haemodynamic studies. J. Physiol. Pharmacol. 2002; 53(1): 75-84

24. Jochem J. Haematological, blood gas and acid-base effects of central histamine-induced reversal of critical haemorrhagic hypotension in rats. J. Physiol. Pharmacol. 2001; 52(3): 447-458.

25. Giuliani D., Ottani A., Altavilla D., Bazzani C., Squadrito F., Guarini S. Melanocortins and the cholinergic anti-inflammatory pathway. Adv. Exp. Med. Biol. 2010; 681: 71-87, doi: 10.1007/978-1-4419-6354-3 6 .

26. Guarini S., Bertolini A, Lancellotti N., Rompianesi E., Ferrari W. Different cholinergic pathways are involved in the improvement induced by CCK- 8 and by ACTH-(1-24) in massive acute hemorrhage, in rats. Pharmacol. Res. Commun. 1987; 19(7): 511-516, doi: 10.1016/0031-6989(87)90111-1.

27. Gaw A.J., Hills D.M., Spraggs C.F. Characterization of the receptors and mechanisms involved in the cardiovascular actions of sCCK- 8 in the pithed rat. Br. J. Pharmacol. 1995; 115(4): 660-664, doi: 10.1111/j.1476-5381.1995. tb14983.x. 